\title{
Transcriptome mining, functional characterization, and phylogeny of a large terpene synthase gene family in spruce (Picea spp.)
}

Christopher I Keeling ${ }^{1}$, Sabrina Weisshaar ${ }^{2}$, Steven G Ralph³ ${ }^{3}$ Sharon Jancsik ${ }^{1}$ Britta Hamberger ${ }^{4}$, Harpreet K Dullat ${ }^{1}$, Jörg Bohlmann ${ }^{1 *}$

\begin{abstract}
Background: In conifers, terpene synthases (TPSs) of the gymnosperm-specific TPS-d subfamily form a diverse array of mono-, sesqui-, and diterpenoid compounds, which are components of the oleoresin secretions and volatile emissions. These compounds contribute to defence against herbivores and pathogens and perhaps also protect against abiotic stress.

Results: The availability of extensive transcriptome resources in the form of expressed sequence tags (ESTs) and full-length cDNAs in several spruce (Picea) species allowed us to estimate that a conifer genome contains at least 69 unique and transcriptionally active TPS genes. This number is comparable to the number of TPSs found in any of the sequenced and well-annotated angiosperm genomes. We functionally characterized a total of 21 spruce TPSs: 12 from Sitka spruce (P. sitchensis), 5 from white spruce (P. glauca), and 4 from hybrid white spruce (P. glauca $\times P$. engelmannii), which included 15 monoterpene synthases, 4 sesquiterpene synthases, and 2 diterpene synthases.
\end{abstract}

Conclusions: The functional diversity of these characterized TPSs parallels the diversity of terpenoids found in the oleoresin and volatile emissions of Sitka spruce and provides a context for understanding this chemical diversity at the molecular and mechanistic levels. The comparative characterization of Sitka spruce and Norway spruce diterpene synthases revealed the natural occurrence of TPS sequence variants between closely related spruce species, confirming a previous prediction from site-directed mutagenesis and modelling.

\section{Background}

Conifer trees (order Coniferales; Gymnosperms) are extremely long-lived plants that must confront a multitude of biotic and abiotic stresses that vary with the season and over their lifetime. Conifers have evolved several resistance mechanisms that repel, kill, inhibit, or otherwise reduce the success of herbivores and pathogens. These mechanisms include both mechanical and chemical defences that can be present constitutively or that are induced upon challenge [1,2]. As a major part of their constitutive and inducible defensive repertoire, conifers produce an abundant and complex mixture of terpenoids in the form of oleoresin secretions and

\footnotetext{
* Correspondence: bohlmann@msl.ubc.ca

'Michael Smith Laboratories, University of British Columbia, 301-2185 East Mall, Vancouver BC, V6T 1Z4, Canada

Full list of author information is available at the end of the article
}

volatile emissions [2,3]. The diversity of the terpenoids in conifers suggests that, like in other plants [4], an arms race has unfolded in the interactions of conifers with other organisms through the production of specialized (i.e., secondary) metabolites. The diversity of conifer terpenoids includes predominantly monoterpenes, sesquiterpenes and diterpenes, which originate from the activity of a family of terpene synthases (TPSs), and other enzymes, such as cytochromes P450, that may functionalize some of the terpenes $[2,5]$.

Despite much work on individual conifer TPSs [2], the total number of TPSs present in any one conifer species is not yet known since no conifer genome has been sequenced to date. In contrast, the sequenced and annotated genomes of several angiosperm species provide an indication of the diversity of TPSs we might expect to see in any one plant species. For example, the genes

\section{(Ciomed Central}


encoding putatively active mono-, sesqui-, and di-TPSs number at least 32 in the Arabidopsis (Arabidopsis thaliana) genome [6], at least 31 in the rice (Oryza sativa) genome [7], at least 32 in the poplar (Populus trichocarpa) genome [8], and at least 69 in the genome of a highly inbred grapevine (Vitis vinifera) Pinot Noir variety $[9,10]$. All of these angiosperm genomes contain clusters of duplicated TPS genes. The large genome size of conifers and the diversity of their terpenoid profiles may suggest a similarly sized or potentially larger TPS gene family in conifer species. However, targeted BAC sequencing of a few conifer TPSs from white spruce (Picea glauca) did not reveal any genomic clustering of multiple TPS genes in this conifer genome $[11,12]$.

Most of our current knowledge of the size, functional diversity and phylogeny of gymnosperm TPSs is based on targeted cDNA cloning and characterization in two conifer species, grand fir (Abies grandis) and Norway spruce (P. abies), along with a few TPSs in other gymnosperms [2]. In grand fir, 11 different TPS genes have been functionally characterized [13]. Martin et al. [14] described a set of 9 different TPSs in Norway spruce ( $P$. abies) and examined the phylogeny of 29 gymnosperm TPSs, all of which fell into the gymnosperm-specific TPS-d subfamily. A deeper understanding of the diversity and functional complexity of the conifer TPS- $d$ subfamily requires additional gene discovery by transcriptome mining. Large collections of expressed sequence tags (ESTs) and fulllength cDNAs (FLcDNAs) exist for several conifer species [15-17] and provide a rich resource for identifying and functionally characterizing new TPSs.

Here, we have analyzed the ESTs and FLcDNAs from Sitka spruce ( $P$. sitchensis), white spruce ( $P$. glauca), and hybrid white spruce $(P$. glauca $\times P$. engelmannii $)$ to identify a comprehensive set of expressed members of the spruce TPS gene family. We have functionally characterized several members from each species for a total of 21 newly characterized spruce TPSs. This work complements previous work in Norway spruce [14] and provides a molecular basis from which to explain much of the chemical complexity of the oleoresin and volatile terpenoids in spruce. Results of the functional gene characterization are discussed in the context of previously reported terpenoid metabolite profiles of oleoresin and volatile emissions in Sitka spruce.

\section{Results and Discussion}

Identification of unique TPS sequences and isolation of full-length TPS CDNA clones

The in silico analysis of 443,665 spruce ESTs identified a total of 506 ESTs corresponding to putative TPSs (Table 1). Assembly of these ESTs into contigs and singlets allowed us to estimate the minimum number of actively expressed TPS genes in each of the three spruce species of our analysis. We identified 69 unique TPS sequences in white spruce, 55 in Sitka spruce, and 20 in hybrid white spruce. Although the rate of gene discovery was dependent on the depth of EST sequencing (Table 1), the substantially deeper EST sequence coverage in white spruce $(242,931$ ESTs) did not result in a proportional increase of TPS discovery relative to Sitka spruce $(174,384$ ESTs) and hybrid white spruce $(26,350$ ESTs), suggesting that the majority of expressed TPSs in the tissues sequenced were captured at the depth of sequencing probed in white spruce and Sitka spruce. The estimate of at least 69 TPSs in white spruce is comparable to the number of putatively active TPS genes found in the sequenced genomes of angiosperms and is perhaps a good approximation of the total number of transcriptionally active TPS genes in a conifer species. From the set of assembled TPS sequences, we examined approximately 170 of the corresponding cDNA clones by restriction digest, colony PCR and/or sequencing to identify those which contained full ORFs. Eighteen FLcDNA clones were selected for subcloning and functional characterization. In addition, three full-length TPS cDNA clones were obtained by RACE cloning or homology-based PCR cloning. As the Treenomix project [16], which generated the available cDNA clones focused its FLcDNA program on Sitka spruce, the majority of the full-length TPS cDNA clones were from this species (12 FLcDNAs). Five full-length TPS cDNA clones originated from white spruce, and four from hybrid white spruce.

\section{Functional characterization of recombinant TPS enzymes}

Most previously described conifer TPSs are multiproduct enzymes $[14,18]$, and because the identity and relative abundance of TPS products are very sensitive to small changes in amino acid sequence [19-24], it is not possible to accurately predict function based solely upon

Table 1 In silico identification of TPSs in the EST databases of Sitka spruce, white spruce, and hybrid white spruce

\begin{tabular}{lcccccc}
\hline Spruce Species & Total ESTs & Total Singlets Plus Contigs & TPS ESTs* & TPS Singlets & TPS Contigs & Total TPSs \\
\hline White & 242,931 & 59,449 & 181 & 36 & 33 & 69 \\
Sitka & 174,384 & 37,533 & 282 & 25 & 30 & 55 \\
Hybrid White & 26,350 & 13,279 & 43 & 10 & 10 & 20
\end{tabular}

${ }^{*}$ Conifer TPS protein sequences available from NCBI were used to query the three species-specific EST databases using the tBLASTn module of WU-BLAST 2.0 and an E-value cut off of $1 \times 10^{-5}$. The resulting outputs were filtered to exclude duplicates, and then assembled separately by species using CAP3 [49]. The total TPSs represents an estimated minimum number of unique TPSs found in each species. 
amino acid sequence similarity/phylogeny. While it might be possible to infer a TPS gene function from the chemical phenotype of a corresponding plant mutant, the genetic resources for such an approach are available only for a very few model systems such as Arabidopsis [25]. Instead, in most systems, the functional annotation of each TPS requires expression and enzyme characterization of recombinant protein.

Recombinant spruce TPSs were expressed in E. coli and purified by $\mathrm{Ni}$-affinity chromatography before assaying each individually with geranyl diphosphate (GPP), farnesyl diphosphate (E,E-FPP), and geranylgeranyl diphosphate (E,E,E-GGPP), the three respective transprenyl diphosphate substrates of conifer monoterpene synthases, sesquiterpene synthases, and diterpene synthases. Since two recent reports described the occurrence and conversion of cis-prenyl diphosphate substrates in tomato [26-28], we also assessed if spruce is likely to produce these additional TPS substrates. Mining of all available spruce EST sequences did not reveal the presence of prenyltransferases for the formation of cis-prenyl diphosphate substrates (D. Hall and J. Bohlmann; unpublished results).

In the following sections we describe the specific functional characterization of the 21 spruce TPSs (Figure 1). With one exception, each of these TPSs only made significant use of one of the substrates. Based upon functional characterization, the 21 TPSs comprised

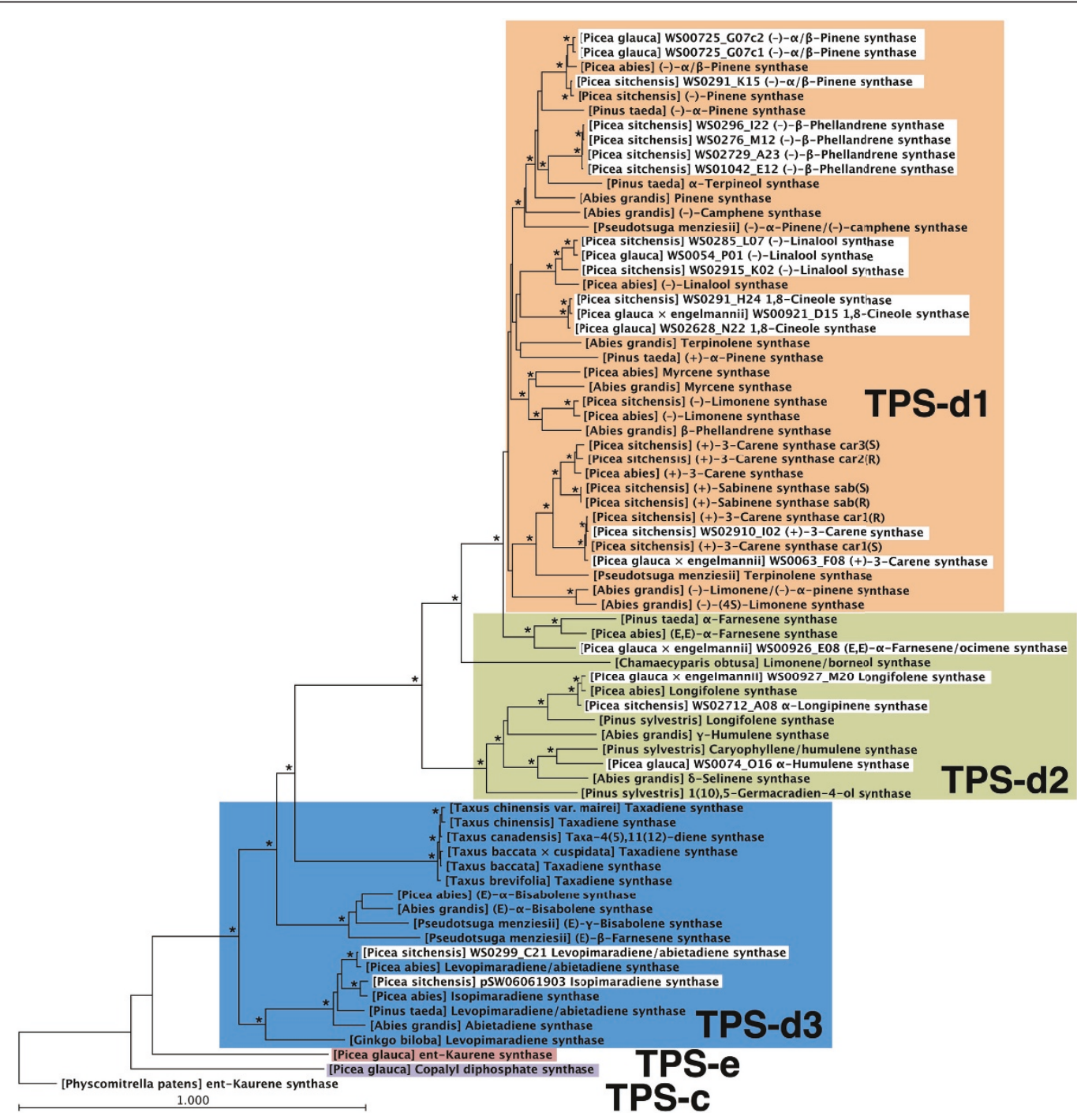

Figure 1 Phylogeny of functionally characterized gymnosperm TPSs. The ent-kaurene synthase from Physcomitrella patens was included as an outgroup. TPSs described in this paper are shown with white background. Protein alignments were prepared using MUSCLE [54] and phylogenetic trees were constructed using the neighbour-joining method with 100 bootstrap repetitions (asterisks are given at clades supported by $80 \%$ and higher bootstrap values), within CLC Main Workbench (CLC bio, Århus, Denmark). 
15 monoterpene synthases, 4 sesquiterpene synthases, and 2 diterpene synthases. The product identities and abundance for each TPS, including quantitative composition of multi-product profiles, is shown in Table 2, and representative GCMS traces are shown in Figures 2, 3 , and 4. A summary of the functional annotation along with NCBI GenBank accession numbers appears in Table 3. Results of the functional TPS characterization are discussed in the context of previously reported terpenoid metabolite profiles in Sitka spruce genotype FB3-425 [see Supplemental Tables in [29]], from which many of the functionally characterized TPS FLcDNAs were isolated. Terpenoid profiles are also available from a collection of 111 Sitka spruce accessions [30].

\section{Functional characterization of monoterpene synthases:} (-)- $\beta$-phellandrene synthases

We identified four (-)- $\beta$-phellandrene synthases in Sitka spruce (PsTPS-Phel-1, PsTPS-Phel-2, PsTPS-Phel-3, and PsTPS-Phel-4), which shared 99\% amino acid identity with each other, suggesting that these genes represent nearly identical allelic variants or very recently duplicated genes in the two genotypes that they originated from (Table 3). Interestingly, the Sitka spruce (-)- $\beta$-phellandrene synthases were only $70 \%$ identical to the (-)- $\beta$-phellandrene synthase from grand fir [13]. The phylogenetic distance between the grand fir and Sitka spruce (-)- $\beta$-phellandrene synthases (Figure 1) suggests that this specific gene function evolved independently more than once. The identity and approximate quantities of the major $[(-)-\beta$-phellandrene, $(-)-\beta$-pinene, and (-)- $\alpha$-pinene] and minor products were nearly identical between the four Sitka spruce (-)- $\beta$ phellandrene synthases (Table 2), and the major products and their approximate proportions were also the same between the (-)- $\beta$-phellandrene synthases of grand fir and spruce. To the best of our knowledge, a (-)- $\beta$-phellandrene synthase has not previously been reported in any other species of spruce $[14,31]$. In Sitka spruce, $\beta$-phellandrene is a major component of the constitutive monoterpene fraction in inner and outer stem tissue and in needles [see Supplemental Tables in [29]]. In stems of Sitka spruce, accumulation of $\beta$-phellandrene increased in response to treatment of trees with methyl jasmonate (MeJA) or insect attack [29]. The Sitka spruce (-)- $\beta$-phellandrene synthases identified here are likely responsible for this major monoterpenoid component of Sitka spruce oleoresin.

\section{Functional characterization of monoterpene synthases:} $(-)-\alpha / \beta$-pinene synthases

We characterized one new (-)- $\alpha / \beta$-pinene synthase in Sitka spruce (PsTPS-Pin) and two in white spruce (PgTPS-Pin-1 and PgTPS-Pin-2; both originating from the same genotype) (Tables 1 and 2). These three enzymes clustered closely with the two previously
Table 2 Product profiles of recombinant TPS enzymes based upon total ion current of GCMS analysis on a DB-WAX column

\begin{tabular}{|c|c|c|c|}
\hline TPS & Clone ID & Products* & $\begin{array}{l}\text { Percent } \\
\text { total }\end{array}$ \\
\hline \multicolumn{4}{|c|}{ MONOTERPENE SYNTHASES } \\
\hline \multirow{13}{*}{$\begin{array}{l}\text { PgxeTPS- } \\
\text { Car1 }\end{array}$} & WS0063_F08 & $(+)$-3-Carene & 53.7 \\
\hline & & Terpinolene & 17.2 \\
\hline & & (+)-Sabinene & 5.6 \\
\hline & & Terpinen-4-ol & 5.2 \\
\hline & & $(-)-\alpha$-Pinene & 2.7 \\
\hline & & $\alpha$-Terpineol & 2.6 \\
\hline & & (-)- $\beta$-Phellandrene & 2.3 \\
\hline & & Myrcene & 2.2 \\
\hline & & $\boldsymbol{\gamma}$-Terpinene & 0.9 \\
\hline & & $\alpha$-Terpinene & 0.6 \\
\hline & & $\alpha$-Phellandrene & 0.3 \\
\hline & & $\alpha$-Thujene & 0.2 \\
\hline & & Others & 6.5 \\
\hline \multirow[t]{10}{*}{ PsTPS-Car1 } & WS02910_102 & $(+)$-3-Carene & 66.4 \\
\hline & & Terpinolene & 16.3 \\
\hline & & (+)-Sabinene & 4.7 \\
\hline & & (-)- $\alpha$-Pinene & 2.7 \\
\hline & & Terpinen-4-ol & 2.5 \\
\hline & & (-)- $\beta$-Phellandrene & 2.1 \\
\hline & & Myrcene & 2.1 \\
\hline & & $\alpha$-Terpineol & 1.4 \\
\hline & & $\gamma$-Terpinene & 0.8 \\
\hline & & Others & 1.1 \\
\hline \multirow[t]{6}{*}{ PgTPS-Cin } & WS02628_N22 & 1,8-Cineole & 89.1 \\
\hline & & (-)- $\alpha$-Terpineol & 4.7 \\
\hline & & $(+)$ - $\alpha$-Pinene & 1.9 \\
\hline & & $\beta$-Pinene & 1.9 \\
\hline & & Unknown & 1.4 \\
\hline & & Myrcene & 1.1 \\
\hline \multirow[t]{7}{*}{ Pg×eTPS-Cin } & WS00921_D15 & 1,8-Cineole & 65.6 \\
\hline & & (-)- $\alpha$-Terpineol & 18.3 \\
\hline & & Myrcene & 4.1 \\
\hline & & $(+)$ - $\alpha$-Pinene & 3.0 \\
\hline & & $\beta$-Pinene & 2.6 \\
\hline & & $\gamma$-Terpinene & 1.8 \\
\hline & & Others & 4.6 \\
\hline \multirow[t]{6}{*}{ PsTPS-Cin } & WS0291_H24 & 1,8-Cineole & 59.0 \\
\hline & & (-)- $\alpha$-Terpineol & 12.2 \\
\hline & & Myrcene & 9.0 \\
\hline & & $\beta$-Pinene & 5.5 \\
\hline & & $(+)$ - $\alpha$-Pinene & 4.7 \\
\hline & & Others & 9.5 \\
\hline PgTPS-Lin & WS0054_P01 & (-)-Linalool & 100 \\
\hline PsTPS-Lin-1 & WS0285_L07 & (-)-Linalool & 100 \\
\hline PsTPS-Lin-2 & WS02915_K02 & (-)-Linalool & 100 \\
\hline \multirow[t]{2}{*}{ PsTPS-Phel-1 } & WS02729_A23 & (-)- $\beta$-Phellandrene & 61.9 \\
\hline & & $(-)-\beta$-Pinene & 18.6 \\
\hline
\end{tabular}


Table 2 Product profiles of recombinant TPS enzymes based upon total ion current of GCMS analysis on a DB-WAX column (Continued)

\begin{tabular}{|c|c|c|c|}
\hline & & $(-)-\alpha$-Pinene & 12.3 \\
\hline & & Myrcene & 5.4 \\
\hline & & $\alpha$-Phellandrene & 1.0 \\
\hline & & $\alpha$-Terpinolene & 0.5 \\
\hline \multirow[t]{6}{*}{ PsTPS-Phel-2 } & WS0296_I22 & (-)- $\beta$-Phellandrene & 61.2 \\
\hline & & $(-)-\beta$-Pinene & 19.8 \\
\hline & & $(-)-\alpha$-Pinene & 12.1 \\
\hline & & Myrcene & 5.5 \\
\hline & & $\alpha$-Phellandrene & 0.9 \\
\hline & & $\alpha$-Terpinolene & 0.5 \\
\hline \multirow[t]{6}{*}{ PsTPS-Phel-3 } & WS0276_M12 & (-)- $\beta$-Phellandrene & 60.9 \\
\hline & & $(-)-\beta$-Pinene & 20.9 \\
\hline & & $(-)-\alpha$-Pinene & 12.5 \\
\hline & & Myrcene & 4.1 \\
\hline & & $\alpha$-Phellandrene & 1.3 \\
\hline & & $\alpha$-Terpinolene & 0.2 \\
\hline \multirow[t]{6}{*}{ PsTPS-Phel-4 } & WS01042_E12 & (-)- $\beta$-Phellandrene & 61.9 \\
\hline & & (-)- $\beta$-Pinene & 19.6 \\
\hline & & $(-)-\alpha$-Pinene & 11.5 \\
\hline & & Myrcene & 5.2 \\
\hline & & $\alpha$-Phellandrene & 1.2 \\
\hline & & $\alpha$-Terpinolene & 0.6 \\
\hline \multirow[t]{2}{*}{ PgTPS-Pin-1 } & WS00725_G07c1 & $(-)-\alpha$-Pinene & 66.7 \\
\hline & & (-)- $\beta$-Pinene & 33.3 \\
\hline \multirow[t]{2}{*}{ PgTPS-Pin-2 } & WS00725_G07c2 & (-)- $\beta$-Pinene & 70.5 \\
\hline & & $(-)-\alpha$-Pinene & 29.5 \\
\hline \multirow[t]{6}{*}{ PsTPS-Pin } & WS0291_K15 & $(-)-\alpha$-Pinene & 83.4 \\
\hline & & (-)- $\beta$-Pinene & 12.6 \\
\hline & & Linalool & 2.1 \\
\hline & & $\beta$-Phellandrene & 1.0 \\
\hline & & Camphene & 0.4 \\
\hline & & Myrcene & 0.4 \\
\hline \multicolumn{4}{|c|}{ SESQUITERPENE SYNTHASES } \\
\hline $\begin{array}{l}\text { PgxeTPS-Far/ } \\
\text { Oci }\end{array}$ & WS00926_E08 & $\begin{array}{l}(E, E)-\alpha \text {-Farnesene/(E)- } \beta \text { - } \\
\text { ocimene }\end{array}$ & 100 \\
\hline \multirow[t]{7}{*}{ PgTPS-Hum } & WS0074_O16 & $\alpha$-Humulene & 42.7 \\
\hline & & (E) $\beta$-Caryophyllene & 37.9 \\
\hline & & $\alpha$-Longipinene & 7.5 \\
\hline & & Longifolene & 3.1 \\
\hline & & $\alpha$-Muurolene & 2.7 \\
\hline & & $\gamma$-Himachalene & 2.6 \\
\hline & & Others & 3.4 \\
\hline \multirow{2}{*}{$\begin{array}{l}\text { PgxeTPS- } \\
\text { Lonf }\end{array}$} & WS00927_M20 & Longifolene & 69.5 \\
\hline & & $\alpha$-Longipinene & 30.5 \\
\hline \multirow[t]{6}{*}{ PsTPS-Lonp } & WS02712_A08 & $\alpha$-Longipinene & 47.7 \\
\hline & & Longifolene & 19.9 \\
\hline & & $\gamma$-Himachalene & 15.9 \\
\hline & & (E) $\beta$-Farnesene & 7.0 \\
\hline & & $\beta$-Longipinene & 3.0 \\
\hline & & Others & 6.4 \\
\hline
\end{tabular}

Table 2 Product profiles of recombinant TPS enzymes based upon total ion current of GCMS analysis on a DB-WAX column (Continued)

\begin{tabular}{llll}
\hline DITERPENE SYNTHASES & & \\
\hline PSTPS-Iso & pSW06061903 & Isopimaradiene & 98.3 \\
& & Sandaracopimaradiene & 1.7 \\
\multirow{2}{*}{ PSTPS-LAS } & WS0299_C21 & Abietadiene & 49.4 \\
& & Levopimaradiene & 23.8 \\
& Neoabietadiene & 23.3 \\
& Palustradiene & 3.5 \\
\hline
\end{tabular}

Compounds were identified by comparison of mass spectra and retention indices with authentic standards if available, and retention indices, and/or mass spectra from Adams [52] and NIST, and combined mass spectra and retention index library searches in MassFinder [53] if standards were not available.

characterized (-)- $\alpha / \beta$-pinene synthases from Sitka spruce [32] and Norway spruce [14] in the TPS-d1 clade (Figure 1). The topology of this group of five $(-)-\alpha / \beta$-pinene synthases suggests that they represent orthologs in the three spruce species of our comparison. The two pairs of $(-)-\alpha / \beta$-pinene synthase genes in white spruce and in Sitka spruce may represent recently duplicated genes or allelic variants in each of these two species. The two white spruce enzymes differed in only four amino acids between each other, and the two Sitka spruce enzymes differed in only six amino acids. The white spruce (-)- $\alpha / \beta$-pinene synthases were approximately $96 \%$ identical with the $(-)-\alpha / \beta$-pinene synthase in Norway spruce, and approximately $96 \%$ identical with the $(-)-\alpha / \beta$-pinene synthases in Sitka spruce. The Sitka spruce (-)- $\alpha / \beta-$ pinene synthases shared approximately $95 \%$ identity with the Norway spruce enzyme. The (-)- $\alpha$-pinene synthase from loblolly pine (Pinus taeda) [33] and the $(-)-\alpha / \beta$-pinene synthase from grand fir [34] clustered outside the group of the spruce $(-)-\alpha / \beta$-pinene synthases (Figure 1). These pine and grand fir (-)-pinene synthases may be the corresponding orthologs outside of the spruce genus.

The two (-)- $\alpha / \beta$-pinene synthases in white spruce (PgTPS-Pin-1 and PgTPS-Pin-2) contained only four amino acid differences: Q/R94, R/G217, S/N221, and $\mathrm{E} / \mathrm{G} 599$, but showed an opposing pattern in the relative amounts of $\alpha$ - and $\beta$-pinene produced by the recombinant enzymes (67:33 and 29:71 $\alpha$-pinene: $\beta$ pinene, respectively, Table 2). Based upon homology modelling with the limonene synthase from Mentha spicata as a template [35], we examined whether any of the four different residues were in or near the active site. Only the residue at 599 (corresponding to M572 of the template) was near the active site. Although this residue was not on the surface of the modelled active site, it was directly behind the residues that contribute 

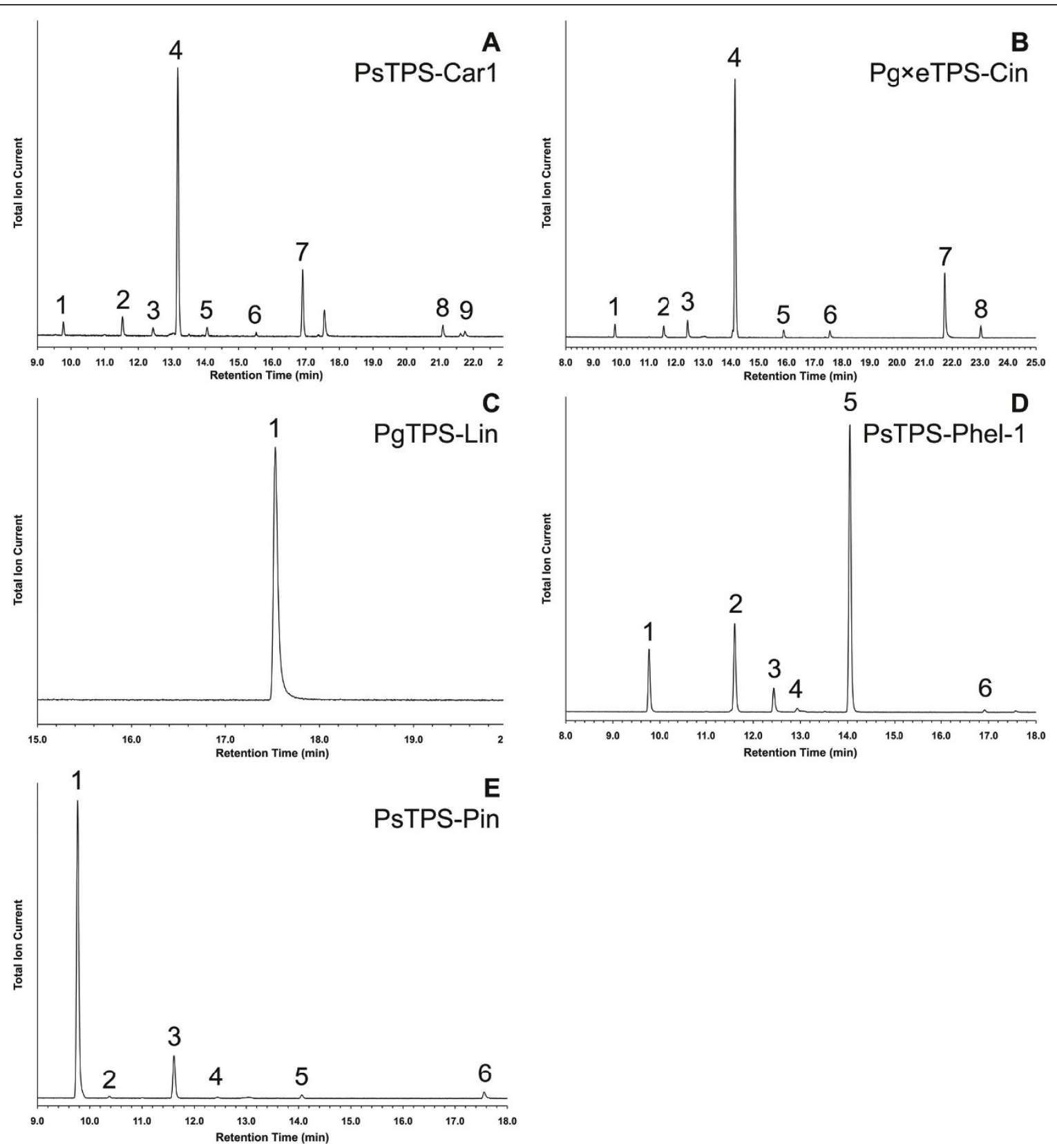

Figure 2 GCMS total ion chromatogram of products formed by the representative monoterpene synthases PsTPS-Car1, PgxeTPS-Cin, PgTPS-Lin, PsTPS-Phel-1, and PsTPS-Pin when incubated with GPP. (A) PSTPS-Car1: 1. (-)- $\alpha$-pinene, 2. (+)-sabinene, 3. myrcene, 4. (+)-3carene, 5. $\beta$-phellandrene, 6. $\gamma$-terpinene, 7. terpinolene, 8. terpinen-4-ol, 9. $\alpha$-terpineol; (B) PgxeTPS-Cin: 1. (+)- $\alpha$-pinene, 2. $\beta$-pinene, 3. myrcene, 4. 1,8-cineole, 5. $\gamma$-terpinene, 6. unknown, 7. (-)- $\alpha$-terpineol, 8. unknown; (C) PgTPS-Lin: 1. (-)-linalool; (D) PsTPS-Phel-1: 1. (-)- $\alpha$-pinene, 2. (-)- $\beta$ pinene, 3. myrcene, 4. $\alpha$-phellandrene, 5. $\beta$-phellandrene, 6. terpinolene; (E) PSTPS-Pin: 1. (-)- $\alpha$-pinene, 2. camphene, 3. (-)- $\beta$-pinene, 4. myrcene, 5. $\beta$-phellandrene, 6 . linalool.

to the active site surface near the tail of the substrate analogue (approximately $8.5 \AA$ away). One might hypothesize that the E/G599 difference was the origin of the observed product differences between the two white spruce PgTPS-Pin variants. However, this residue is glycine in a previously characterized (-)- $\alpha / \beta$-pinene synthase in Sitka spruce [32] and in a previously characterized $(-)-\alpha / \beta$-pinene synthase in Norway spruce [14], which all produce different ratios of $\alpha / \beta$-pinene. Therefore, the three other amino acid differences further from the active site also contributed to product profile differences. 


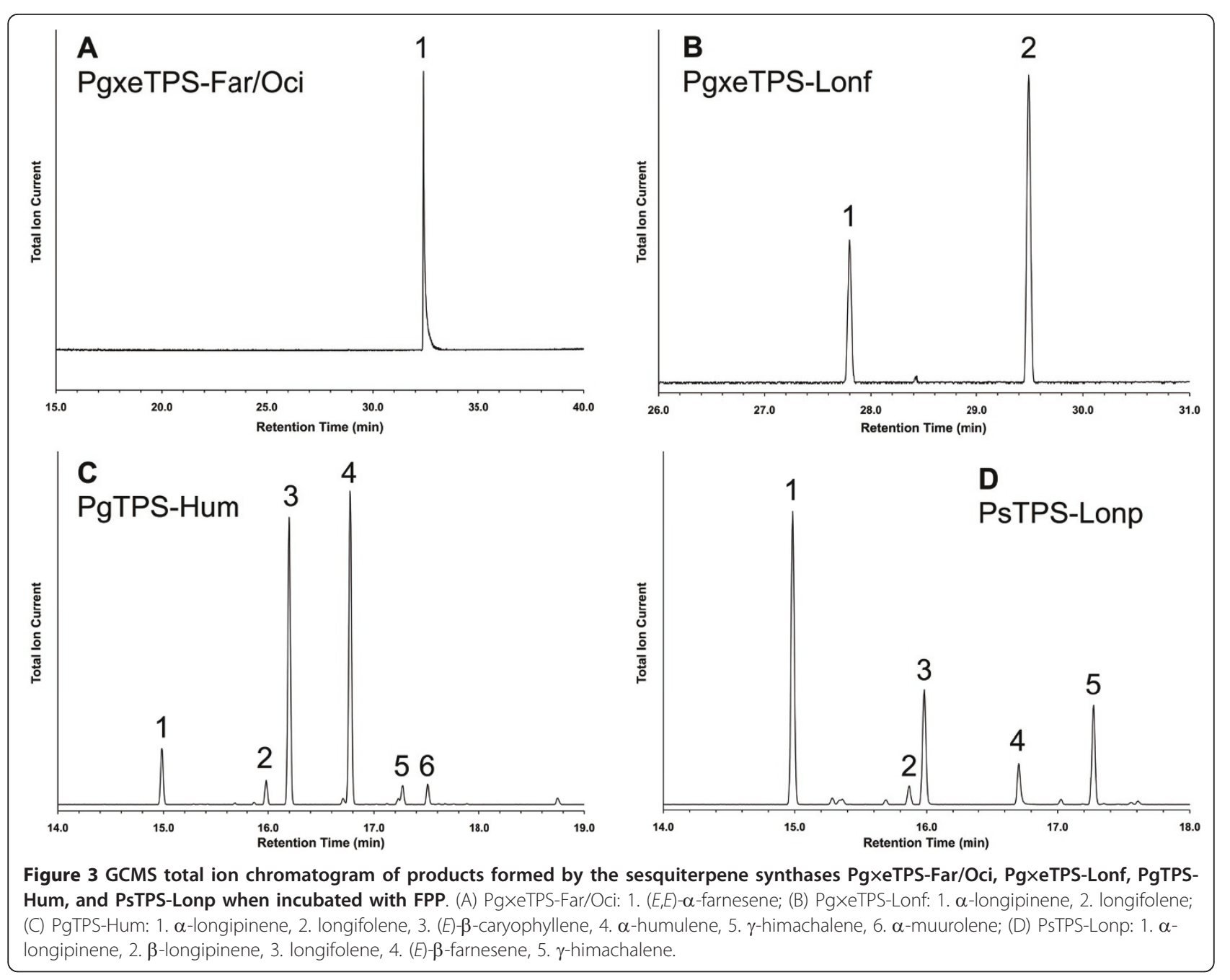

In contrast to the white spruce enzymes PgTPS-Pin-1 and PgTPS-Pin-2, the newly characterized Sitka spruce PsTPS-Pin enzyme produced a larger proportion of $(-)-\beta$-pinene (more than $80 \%$ ) and lesser amounts of (-)- $\alpha$-pinene (less than 13\%), but also had four additional minor products not observed with the PgTPSPin enzymes (Table 2, Figure 2). This product profile was substantially different from that of the second, previously characterized (-)- $\alpha / \beta$-pinene synthase from Sitka spruce, which is dominated by $(-)-\alpha$-pinene (more than $60 \%$ of total product) and lesser amounts of (-)- $\beta$-pinene (less than $20 \%$ of total product) [32]. Of all five spruce $(-)-\alpha / \beta$-pinene synthases, the known Norway spruce enzyme shows the greatest product diversity with (-)- $\beta$-pinene $(57 \%),(-)$ - $\alpha$-pinene $(27 \%)$, and $(-)-\beta$-phellandrene $(11 \%)$ as dominant products along with five other minor constituents [14]. Similar to the white spruce $(-)-\alpha / \beta$-pinene synthase enzymes, the previously characterized and more distantly related $(-)-\alpha / \beta$-pinene synthases from grand fir also produces only (-)- $\alpha$ - and (-)- $\beta$-pinene (42\% and 58\%) [34]. The known product profile of loblolly pine (Pinus taeda) (-)-pinene synthase is substantially different, with mostly (-)- $\alpha$-pinene (79\%) with lesser amounts of $(-)-\beta$-pinene $(4 \%)$ and additional minor products [33]. These comparisons of product profiles and ratios across a set of orthologous, or likely orthologous, multiproduct (-)-pinene synthases show that overall sequence relatedness is not a good indicator of the specific product profiles and ratios even for closely related TPS enzymes.

The monoterpenes (-)- $\alpha$-pinene and (-)- $\beta$-pinene are prominent resin compounds in Sitka spruce $[29,30]$ and in Norway spruce [36,37]. In Norway spruce, induced accumulation of these compounds in bark tissue of MeJA-treated stems is the result of increased enzyme activity, protein abundance, and transcript levels of $(-)-\alpha / \beta$-pinene synthase [38]. Previous work in Sitka spruce also showed strong accumulation of transcripts detected with a $(-)-\alpha / \beta$-pinene synthase probe in 


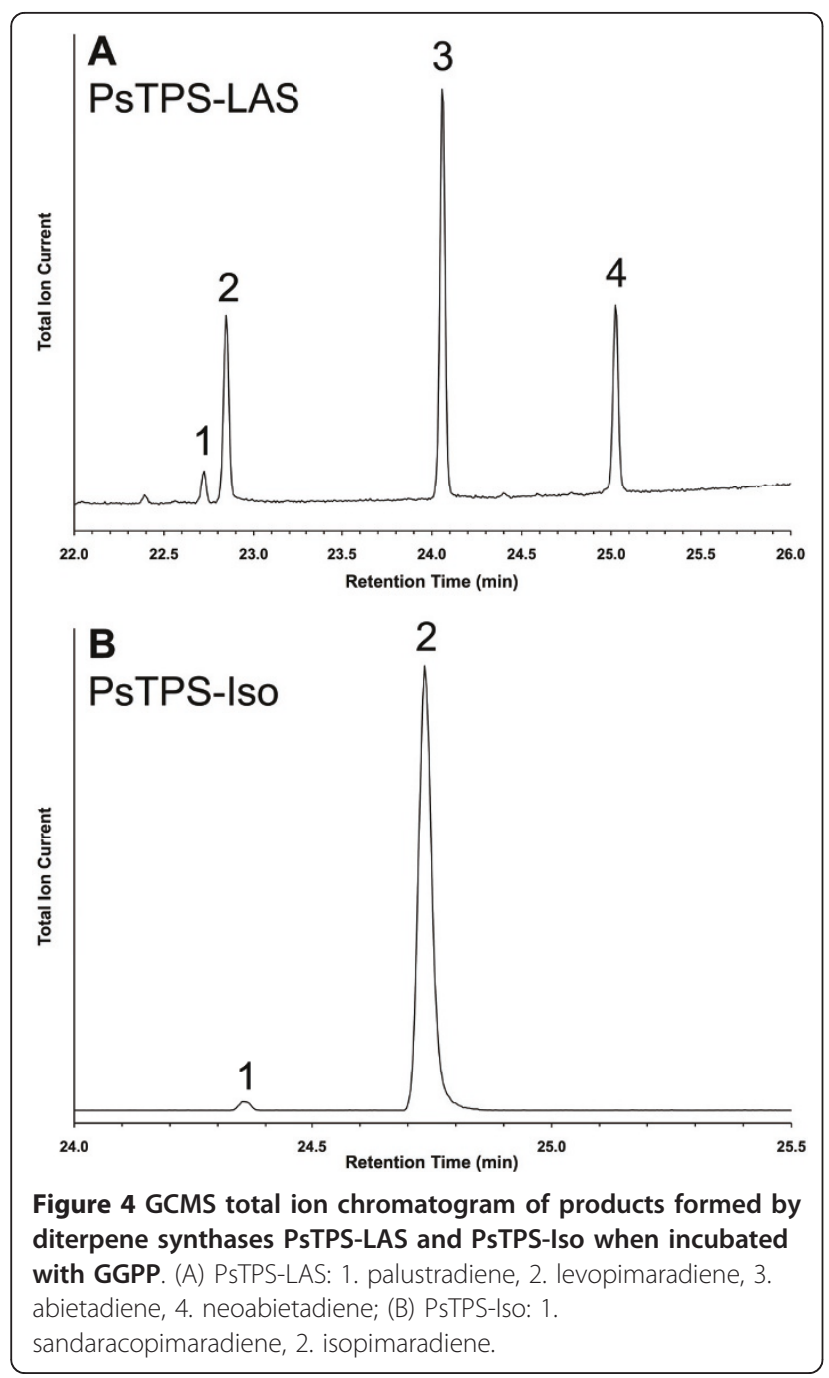

MeJA - and insect-treated stems, both at the site of insect feeding and some distance away [29].

\section{Functional characterization of monoterpene synthases: (-)-Linalool synthases}

We characterized two new (-)-linalool synthases in Sitka spruce (PsTPS-Lin-1 and PsTPS-Lin-2) and one in white spruce (PgTPS-Lin) (Tables 2 and 3, Figure 2). Within the TPS-d1 clade, the Sitka spruce and white spruce (-)-linalool synthases formed a group of orthologous genes with the previously cloned Norway spruce (-)-linalool synthase (PaTPS-Lin) [14] (Figure 1). All of these monoterpene synthases were single-product enzymes producing exclusively an acyclic monoterpene alcohol. They shared 86 to $98 \%$ amino acid sequence identity, with Sitka spruce PsTPS-Lin1 and white spruce PgTPS-Lin being the most closely related. Since the two (-)-linalool synthases from Sitka spruce (91\% identity between them) originated from the same genotype (FB3425; Table 3), they are likely recently duplicated genes.
(-)-Linalool was previously detected as the major volatile emission of MeJA-treated and weevil-attacked Sitka spruce saplings in the genotype FB3-425 [29], similar to the MeJA-induced emission of linalool from Norway spruce [37]. Transcripts detected with a PaTPS-Lin probe were strongly induced in needles of MeJA-treated Sitka spruce [29]. Linalool volatiles are thought to function in indirect defence against herbivores. Apparently, the (-)-linalool emissions in spruce do not originate from the oleoresin reservoirs of severed resin ducts, but from the induced de novo biosynthesis in other tissues. The cloning of (-)-linalool synthase genes from Sitka spruce and white spruce makes it possible to investigate, in future work, the localization of these enzymes and the corresponding transcripts in the needles using the methods of laser-assisted tissue microdissection techniques [39] or immunofluorescence localization [40].

\section{Functional characterization of monoterpene synthases: (+)-3-Carene synthases}

We recently identified a small clade of (+)-3-carene synthases and sabinene synthases in two genotypes of Sitka spruce that are resistant [genotype H898; PsTPScar1(R), PsTPS-car2(R), and PsTPS-sab(R)] or susceptible [genotype Q903; PsTPS-car1(S), PsTPS-car3(S), and PsTPS-sab(S)] to white pine weevil, Pissodes strobi [41]. Here, we identified two additional (+)-3-carene synthases, one in a different genotype of Sitka spruce (genotype FB3-425; PsTPS-Car1), and one in hybrid white spruce (PgxeTPS-Car1) (Tables 2 and 3, Figure 2). These two (+)-3-carene synthases shared approximately $99 \%$ amino acid identity to each other, and were likely the orthologues of the (+)-3-carene synthases PsTPS-car1(R) and PsTPS-car1(S) recently described (Figure 1). Their product profiles were also highly similar for all of the major and most of the minor products. These Sitka and hybrid white spruce (+)-3-carene synthase genes were less similar to the previously characterized Norway spruce (+)-3-carene synthase [42]. A (+)-3-carene synthase gene has not yet been characterized for any conifer outside of the genus Picea. The (+)-3-carene synthases were multiproduct enzymes, producing predominantly $(+)$-3-carene synthase (approximately 53 to $66 \%$ ) and terpinolene (approximately 16\%), with lesser amounts of (+)-sabinene and several other minor products (Table 2). Despite the similarity of product profiles, the Sitka spruce and hybrid white spruce (+)-3-carene synthase both shared only $84 \%$ percent amino acid sequence identity with the Norway spruce TPS. This highlights how even enzymes with fairly divergent primary sequence can share a similar, complex product profile. The two most abundant products of the Sitka spruce $(+)$-3-carene synthases, the monoterpenes (+)-3-carene and terpinolene, have recently been identified as indicators for resistance against weevils in a 
Table 3 Gene name, origin, accession numbers, and functional annotation of spruce TPS

\begin{tabular}{|c|c|c|c|}
\hline Gene & Clone ID (genotype) & Functional Annotation* & NCBI Accession \\
\hline \multicolumn{4}{|c|}{ MONOTERPENE SYNTHASES } \\
\hline PgXeTPS-Car1 & WS0063_F08 (Fa1-1028) & (+)-3-Carene synthase & HQ426152 \\
\hline PsTPS-Car1 & WS02910_I02 (FB3-425) & $(+)$-3-Carene synthase & HQ426167 \\
\hline PgTPS-Cin & WS02628_N22 (PG29) & 1,8-Cineole synthase & HQ426160 \\
\hline PgxeTPS-Cin & WS00921_D15 (Fa1-1028) & 1,8-Cineole synthase & HQ426156 \\
\hline PsTPS-Cin & WS0291_H24 (FB3-425) & 1,8-Cineole synthase & HQ426165 \\
\hline PgTPS-Lin & WS0054_P01 (PG29) & (-)-Linalool synthase & HQ426151 \\
\hline PsTPS-Lin-1 & WS0285_L07 (FB3-425) & (-)-Linalool synthase & HQ426164 \\
\hline PsTPS-Lin-2 & WS02915_K02 (FB3-425) & (-)-Linalool synthase & HQ426168 \\
\hline PsTPS-Phel-1 & WS02729_A23 (FB3-425) & $(-)-\beta$-Phellandrene synthase & HQ426162 \\
\hline PsTPS-Phel-2 & WS0296_122 (FB3-425) & $(-)-\beta$-Phellandrene synthase & HQ426169 \\
\hline PsTPS-Phel-3 & WS0276_M12 (FB3-425) & $(-)-\beta$-Phellandrene synthase & HQ426163 \\
\hline PsTPS-Phel-4 & WS01042_E12 (Gb2-229) & $(-)-\beta$-Phellandrene synthase & HQ426159 \\
\hline PgTPS-Pin-1 & WS00725_G07c1 (PG29) & $(-)-\alpha / \beta$-Pinene synthase & HQ426153 \\
\hline PgTPS-Pin-2 & WS00725_G07c2 (PG29) & (-)- $\alpha / \beta$-Pinene synthase & HQ426154 \\
\hline PsTPS-Pin & WS0291_K15 (FB3-425) & $(-)-\alpha / \beta$-Pinene synthase & HQ426166 \\
\hline \multicolumn{4}{|c|}{ SESQUITERPENE SYNTHASES } \\
\hline PgxeTPS-Far/Oci & WS00926_E08 (Fa1-1028) & $(E, E)-\alpha$-Farnesene/(E)- $\beta$-ocimene synthase & HQ426157 \\
\hline PgTPS-Hum & WS0074_O16 (PG29) & $\alpha$-Humulene synthase & HQ426155 \\
\hline PgxeTPS-Lonf & WS00927_M20 (Fa1-1028) & Longifolene synthase & HQ426158 \\
\hline PsTPS-Lonp & WS02712_A08 (FB3-425) & $\alpha$-Longipinene synthase & HQ426161 \\
\hline \multicolumn{4}{|c|}{ DITERPENE SYNTHASES } \\
\hline PSTPS-IsO & pSW06061903 (Haney 898) & Isopimaradiene synthase & HQ426150 \\
\hline PSTPS-LAS & WS0299_C21 (FB3-425) & Levopimaradiene/abieta-diene synthase & HQ426170 \\
\hline
\end{tabular}

*Functional annotation is based on the main terpenoid product(s) of recombinant enzymes expressed in E. coli. Most TPSs produced multiple products, as shown in Table 2.

particular geographic region of Sitka spruce origin [30]. Substantial variation exists in the levels of $(+)$-3-carene across the range of Sitka spruce [30]. The cloning of (+)-3-carene synthases from resistant and susceptible Sitka spruce enabled a detailed characterization of the genetic variability and the molecular underpinnings of (+)-3-carene formation in resistant and susceptible genotypes [41]. Previous work in Sitka spruce showed MeJAand weevil-induced accumulation of transcripts hybridizing to the Norway spruce $(+)-3$-carene synthase probe [29]. Similarly, (+)-3-carene synthase was very strongly induced at the transcript, protein, and enzyme activity levels in Norway spruce treated with MeJA [38].

\section{Functional characterization of monoterpene synthases: 1,8-Cineole synthases}

In each of the three spruce species studied we identified and characterized a single 1,8-cineole synthase, PgTPSCin, PgxeTPS-Cin, and PsTPS-Cin (Tables 2 and 3, Figure 2). The three enzymes shared approximately $99 \%$ sequence identity to each other and form a distinct group in the TPS-d1 clade most closely related to the linalool synthases. The 1,8-cineole synthases and the linalool synthases are among only a few known conifer monoterpene synthases that produce mainly oxygenated monoterpenes instead of olefins. All three 1,8-cineole synthases were multi-product enzymes with the amount of the major 1,8-cineole product varying from approximately $60 \%$ of total product for PsTPS-Cin to approximately $90 \%$ for PgTPS-Cin. These three spruce enzymes also had similar profiles of minor products $(-)-\alpha-$ terpineol, $(+)-\alpha$-pinene, $\beta$-pinene, myrcene and others (Table 2 and Figure 2). Although 1,8-cineole has been identified as a monoterpenoid component in needles and MeJA-induced volatile emissions of Norway spruce [37], and has recently been shown to inhibit attraction in the field and response of an olfactory receptor neuron to pheromone of a spruce beetle [43], this is the first characterization of gymnosperm TPSs that produce this compound.

\section{Functional characterization of sesquiterpene synthases}

A complex blend of sesquiterpenes is found in minor quantities in the oleoresin of conifers, including Sitka spruce [29] and Norway spruce [37]. Sesquiterpenes are also present in the MeJA-induced volatile emissions of Norway spruce [37] and in the MeJA- and weevilinduced volatile emissions in Sitka spruce [29]. For the 
three spruce species of our EST analysis, we cloned and functionally characterized four FLcDNAs, PgTPS-Hum, PgxeTPS-Lonf, PsTPS-Lonp, and PgxeTPS-Far/Oci, as bona fide sesquiterpene synthases (Tables 2 and 3; Figure 3). PgTPS-Hum, PgxeTPS-Lonf, PsTPS-Lonp only used FPP as substrate and were typical multi-product conifer sesquiterpene synthases such as those first identified in grand fir [18]. In contrast, PgxeTPS-Far/Oci was active both with GPP and FPP. This enzyme produced only $(E, E)-\alpha$-farnesene, when assayed with FPP, and $(E)$ - $\beta$-ocimene and a small amount of myrcene, when assayed with GPP. The previously characterized $(E, E)$ - $\alpha$-farnesene synthases cloned from Norway spruce [14] and loblolly pine [33] did not show this dual substrate utilization $[14,33]$, although it has been observed with apple (Malus $\times$ domestica) $(E, E)$ - $\alpha$-farnesene synthase [44]. (E,E)- $\alpha$-farnesene is major sesquiterpene component of the MeJA- and weevil-induced volatile emissions of Sitka spruce [29].

PgTPS-Hum produced predominantly $\alpha$-humulene (approximately $43 \%$ ) and $(E)-\beta$-caryophyllene (approximately $38 \%$ ), along with several minor products, similar to the $\alpha$-humulene synthase previously characterized in Scots pine (Pinus sylvestris) [45]. PgxeTPS-Lonf produced longifolene (approximately $70 \%$ ) and $\alpha$-longipinene (approximately 30\%). Unlike the longifolene synthase from Norway spruce [14], this TPS did not produce other minor products. Sitka spruce PsTPSLonp produced predominantly $\alpha$-longipinene (approximately 48\%) but also substantial amounts of longifolene, $\gamma$-himachalene, and other minor products. Longifolene and $\alpha$-longipinene were previously found in the resin of untreated and induced Sitka spruce stems [29] and weevil attack caused an increase of these compounds.

PgTPS-Hum, Pg $\times$ eTPS-Lonf, PsTPS-Lonp belong to the TPS- $\mathrm{d} 2$ clade of the gymnosperm TPS- $\mathrm{d}$ subfamily, together with other conifer multi-product sesquiterpene synthases (Figure 1). The hybrid white spruce PgxeTPSFar/Oci appeared to be orthologous with farnesene synthases from loblolly pine and Norway spruce in the TPS-d1 clade.

\section{Functional characterization of diterpene synthases}

Two paralogous diterpene synthases, PsTPS-LAS and PsTPS-Iso, were characterized in Sitka spruce (Tables 2 and 3, Figure 4). These TPSs shared 90\% identity and they are the orthologues of levopimaradiene/abietadiene synthase (PaTPS-LAS) and isopimaradiene synthase (PaTPS-Iso) from Norway spruce [14] (Figure 1). They belong to the TPS- $\mathrm{d} 3$ clade of the gymnosperm TPS-d family. PsTPS-LAS produced a similar multi-product profile as its ortholog in Norway spruce, composed of abietadiene (49\%), levopimaradiene (24\%), neoabietadiene $(23 \%)$, and palustradiene (4\%). In contrast to the single-product isopimaradiene synthase from Norway spruce [14], Sitka spruce PsTPS-Iso produced minor amounts of sandaracopimaradiene $(2 \%)$ in addition to isopimaradiene (98\%) (Table 2, Figure 4). PsTPS-Iso is the first gymnosperm TPS identified to naturally produce sandaracopimaradiene, albeit in minor amounts. An ent-sandaracopimaradiene synthase has been characterized in rice [46].

PsTPS-LAS and PsTPS-Iso play an important role in the overall diterpene resin acid defence systems of Sitka spruce. The six products of the two Sitka spruce diterpene synthases are present as the corresponding diterpene resin acids in the oleoresin of Sitka spruce stem tissues [29]. Accumulation of all of these diterpene resin acids was induced by MeJA treatment or insect attack, along with increased transcript levels detected with the orthologous PaTPS-LAS and PaTPS-Iso probes [29].

The sequences of PsTPS-LAS and PaTPS-LAS differed by only 12 amino acids, and PsTPS-Iso and PaTPS-Iso differed by only 35 amino acids. In a detailed investigation of the PaTPS-LAS and PaTPS-Iso enzymes, using reciprocal site-directed mutagenesis and domainswapping, we have recently shown that four amino acid residues determine the different product profiles of these Norway spruce diterpene synthases [24]. These product-determining residues are identical between the levopimaradiene/abietadiene synthases (PsTPS-LAS and PaTPS-LAS) in Sitka and Norway spruce, consistent with their similar product profiles. However, only three of these residues are identical between the isopimaradiene synthases (PsTPS-Iso and PaTPS-Iso) in Sitka and Norway spruce; the fourth residue (V732) is the same as that found in the Norway spruce levopimaradiene/ abietadiene synthase. In our previous study [24], the corresponding reciprocal L725V mutation obtained by site-directed mutagenesis of PaTPS-Iso resulted in the formation of sandaracopimaradiene as a minor product. This product profile change is consistent with the new observation that the isopimaradiene synthase from Sitka spruce (PsTPS-Iso) naturally produced sandaracopimaradiene as a minor compound (Table 2, Figure 4). Overall, these results highlight how mutations produced in the laboratory that determine product profile differences also exist in nature and do result in the evolution of altered TPS product profiles between species or genotypes.

\section{Phylogeny of gymnosperm TPSs}

All known conifer TPSs of specialized (i.e., secondary) metabolism are members of the gymnosperm-specific TPS-d subfamily, which is a distinct clade of the larger plant TPS gene family [47]. The TPS-d subfamily has been subdivided into three clades TPS-d1 through TPSd3 based on a previous phylogeny of 29 gymnosperm 
TPSs [14]. Here, we have substantially expanded the phylogeny of functionally characterized gymnosperm TPSs to a total of 72 members (Figure 1), of which 41 are from spruce species with 20 different TPSs from Sitka spruce. The number of TPSs functionally characterized in Sitka spruce is one of the largest for any species, but is not yet approaching our in silico minimum estimate for the number of TPSs in a spruce genome (at least 69 transcriptionally active TPS genes). The diverse set of newly characterized spruce TPSs broadly represent the major TPS-d1, TPS-d2 and TPS-d3 clades, and allowed us to identify groups of likely orthologous TPS genes across the spruce species. Examples for such groups of orthologous TPSs in the TPS-d1 clade are the $(-)-\alpha / \beta$-pinene synthases, the (-)-linalool synthases, $(E$, $E)-\alpha$-farnesene synthases; in the TPS-d2 clade are the longifolene synthases; and in the TPS-d3 clade are the levopimaradiene/abietadiene synthases and isopimaradiene synthases. These groups represent genes whose functions had apparently evolved prior to speciation of the spruce genus. In the TPS- $\mathrm{d} 3$ group of conifer diterpene synthases, the basal function of a multi-product levopimaradiene/abietadiene synthase had apparently evolved prior to conifer speciation, as this function exists in a group of closely related genes from the genera Abies, Pinus and Picea.

Overall, the large diversity of gene functions among the many closely related genes of the conifer TPS- $d 1$ group illustrates the many events of gene duplications and sub- or neo-functionalizations that have occurred in the evolution of this amazing family of conifer genes of specialized metabolism. The functionally identified spruce TPS genes account for many of the major and minor terpenoid compounds of the defensive oleoresin and volatile emissions. However, there are several distinct types of TPSs still to be found in spruce based upon the terpenoid components identified in oleoresin. Based on the current phylogeny of functionally characterized spruce TPSs, we predict that most of the remaining TPSs to be identified will be highly similar in sequence to previously identified TPS, but with the possibility of diverse function due to relatively minor sequence divergence.

In contrast to the many duplicated TPS-d genes of terpenoid specialized metabolism, the related spruce TPS genes of general gibberellin phytohormone biosynthesis, specifically ent-copalyl diphosphate synthase (TPS-c) and ent-kaurene synthase (TPS-e), appear to be expressed as single copy genes [12]. These primary metabolism TPS genes are basal to the specialized metabolism genes and are the descendants of an ancestral plant diterpene synthase similar to the one found in the non-vascular plant Physcomitrella patens $[12,48]$. The mechanisms that suppress manifestation or retention of
TPS gene duplication in diterpenoid primary metabolism and those that enhance TPS gene duplication and functional diversification in specialized metabolism in a conifer genome are not known but are worthy of future investigation. The high functional plasticity of the TPS-d family and the great diversity of terpenoids produced may impart fitness advantages against a multitude of pests and pathogens. We speculate that the TPS-d genes of specialized metabolism originating from gene duplication are slower, or less likely, to become inactive pseudogenes compared to those genes with less functional plasticity in primary metabolism.

\section{Conclusions}

Based upon estimates from EST and FLcDNA sequencing in three species of spruce, the TPS gene family in conifers appears to be at least of comparable size to those found in angiosperms with sequenced genomes. This study highlights the great diversity of TPSs of specialized metabolism in conifers, which resulted from gene duplication and functional diversification. Functional differences can occur naturally due to small differences in amino acid sequence.

\section{Methods}

In silico identification of spruce terpene synthases in the EST and FLCDNA databases

Quality trimmed and filtered nucleotide sequences were obtained from spruce genomic resources developed in the Genome Canada-funded Treenomix (http://www. treenomix.ca) and Arborea (http://www.arborea.ulaval. ca) projects as follows: white spruce $(242,931 \mathrm{ESTs})$, Sitka spruce $(174,384$ ESTs), and hybrid white spruce (also referred to as interior spruce; 26,350 ESTs) $[15,16]$. Conifer TPS protein sequences available from NCBI were used to query the three species-specific databases using the tBLASTn module of WU-BLAST 2.0 and an E-value cut off of $1 \times 10^{-5}$. The resulting outputs were filtered to exclude duplicates, and then assembled separately by species using CAP3 [49] using an overlap of 40 bp and a percent identity of $95 \%$. The assembled TPS candidate sequences were then tentatively annotated using NCBI BLASTx using the $\mathrm{nr}$ database (downloaded Oct. 2008).

Selection of FLCDNA clones for functional characterization Authentic cDNA clones corresponding to the aboveidentified TPS candidate sequences were examined further by restriction digest, colony PCR, and/or sequencing. Those clones that potentially contained a full-length TPS cDNA (i.e. complete ORF) were fully sequenced and if a unique full-ORF TPS was found, the insert was subcloned for expression as described below. In one case, two full ORFs (WS00725_G07c1, WS00725_G07c2) were 
obtained by 5 -RACE and the full-length genes were subsequently cloned into pCR Blunt II TOPO (Invitrogen).

\section{Cloning of PsTPS-Iso}

Because of our particular interest in conifer diTPSs $[12,24]$ and the low abundance of putative diTPSs in the ESTs, we chose to isolate an isopimaradiene synthase (PsTPS-Iso) cDNA from Sitka spruce using homologybased cloning to allow functional comparison with its putative levopimaradiene/abietadiene synthase paralog (PsTPS-LAS, WS0299_C21, described here). Examination of the spruce EST resources $[15,16]$ identified a 3'-read for clone WS00752_D05 from white spruce with high similarity to the isopimaradiene synthase from Norway spruce (PaTPS-Iso; [14]). Full sequencing of this cDNA clone indicated that it was an incomplete transcript. Using PCR with primers designed for the 3'-UTR of this sequence and the 5'-UTR of WS0299_C21, we amplified a 2,700 bp cDNA from the bark of methyl jasmonatetreated Sitka spruce (genotype Haney 898). The amplicon was cloned into pCR Blunt II TOPO and fully sequenced (PSTPS-Iso, pSW06061903).

\section{Expression and purification of recombinant TPS enzymes}

TPS cDNAs were amplified using proof-reading polymerase (Phusion, Finnzymes, Espoo, Finland) and subcloned into NdeI/HindIII-digested pET28b(+) (Novagen) using a sticky-end PCR approach [50], or via topoisomerase-mediated insertion into pET100 TOPO/D or pET200 TOPO/D (Invitrogen). All resulting recombinant proteins were full-length and $\mathrm{N}$-terminally Histagged. Expression constructs were fully sequence verified.

Plasmids were transformed into chemically competent C41 E. coli cells (http://www.overexpress.com) containing the pRARE 2 plasmid (coding for rare tRNAs) prepared from Novagen Rosetta 2 cells (EMD Biosciences, Inc., Madison, WI, USA). Luria-Bertani medium ( $5 \mathrm{~mL}$ ) containing appropriate antibiotics was inoculated with three individual colonies and cultured overnight at $37^{\circ} \mathrm{C}$, $220 \mathrm{rpm}$. Terrific Broth medium $(50 \mathrm{~mL})$ containing appropriate antibiotics was then inoculated with $0.5 \mathrm{~mL}$ of the overnight culture and grown in a $250 \mathrm{~mL}$ baffle flask at $37^{\circ} \mathrm{C}$ and $300 \mathrm{rpm}$ until an optical density at $600 \mathrm{~nm}$ of at least 0.8 was reached. Cultures were then cooled to $16^{\circ} \mathrm{C}$, induced with $0.2 \mathrm{mM}$ IPTG, and then cultured for approximately $16-20 \mathrm{~h}$ at $16^{\circ} \mathrm{C}$ and $220 \mathrm{rpm}$ before pelleting and freezing.

Cell pellets were resuspended, lysed, and sonicated in (1.5 $\mathrm{mL} \mathrm{g}^{-1}$ pellet) ice cold $20 \mathrm{mM} \mathrm{NaPO}_{4}, 500 \mathrm{mM} \mathrm{NaCl}$, $30 \mathrm{mM}$ imidazole, $0.04 \mathrm{mg} \mathrm{mL}^{-1}$ DNase, $1 \mathrm{mM} \mathrm{MgCl}_{2}$, $5 \mathrm{mM}$ PMSF, and $0.5 \mathrm{mg} \mathrm{mL}^{-1}$ lysozyme, $\mathrm{pH} 7.4$ and then clarified by centrifugation $\left(30 \mathrm{~min}, 12,000 \times g, 4^{\circ} \mathrm{C}\right.$ ). The cleared lysates were applied to His SpinTrap Ni-affinity columns (GE Healthcare, Piscataway, NJ, USA) and eluted with $20 \mathrm{mM} \mathrm{NaPO}_{4}, 500 \mathrm{mM} \mathrm{NaCl}$, and $500 \mathrm{mM}$ imidazole, $\mathrm{pH} 7.4$ at $4^{\circ} \mathrm{C}$ following the manufacturer's protocol. Purified enzymes were desalted at $4^{\circ} \mathrm{C}$ into 25 mM HEPES $\mathrm{pH}$ 7.2, $100 \mathrm{mM} \mathrm{KCl}$, and 10\% glycerol using PD MiniTrap G-25 desalting columns (GE Healthcare) and then used immediately for enzyme assays.

\section{Enzyme assays and gas chromatography-mass spectrometry (GCMS) analyses}

Single-vial enzyme assays were completed in triplicate in $2 \mathrm{~mL}$ amber glass GC sample vials as previously described [51] in three different buffer/substrate combinations with approximately $60 \mu \mathrm{g}$ of purified protein per $500 \mu \mathrm{L}$ assay. Buffers consisted of: monoTPS assays; $25 \mathrm{mM}$ HEPES, pH 7.2, $100 \mathrm{mM} \mathrm{KCl}, 10 \mathrm{mM} \mathrm{MnCl}$, $5 \mathrm{mM}$ fresh DTT, 10\% glycerol, and $51 \mu \mathrm{M}$ GPP (geranyl diphosphate, Sigma-Aldrich, Oakville, ON); sesquiTPS assays; $25 \mathrm{mM}$ HEPES, $\mathrm{pH} 7.2,10 \mathrm{mM} \mathrm{MgCl}$, $5 \mathrm{mM}$ fresh DTT, $10 \%$ glycerol, and $43 \mu \mathrm{M}$ FPP $((E, E)$ farnesyl diphosphate, Sigma-Aldrich); diTPS assays; $50 \mathrm{mM}$ HEPES, pH 7.2, $100 \mathrm{mM} \mathrm{KCl}, 7.5 \mathrm{mM} \mathrm{MgCl}_{2}$, $20 \mu \mathrm{M} \mathrm{MnCl}$, $5 \mathrm{mM}$ fresh DTT, $5 \%$ glycerol, and $37 \mu \mathrm{M}$ GGPP $((E, E, E)$-geranylgeranyl diphosphate, Sigma-Aldrich). Assays were overlaid with $500 \mu \mathrm{L}$ of pentane and incubated at $30^{\circ} \mathrm{C}$ for 90 min after which they were vortexed for $30 \mathrm{~s}$ to denature the proteins and extract the products into the pentane layer. To completely separate the phases prior to GCMS analysis, samples were frozen at $-80^{\circ} \mathrm{C}$ and then the vials were centrifuged for $30 \mathrm{~min}$ at $1,000 \times g$ at $4^{\circ} \mathrm{C}$.

Assay products were analyzed on an Agilent HP-5ms column (5\% phenyl methyl siloxane, $30 \mathrm{~m} \times 250 \mu \mathrm{m}$ ID, $0.25 \mu \mathrm{m}$ film) at $1 \mathrm{~mL} \mathrm{~min}^{-1} \mathrm{He}$ on an Agilent $6890 \mathrm{~N}$ gas chromatograph, 7683B series autosampler (vertical syringe position of 8 to sample the pentane layer), and 5975 Inert XL MS Detector. GC temperature program as fol-

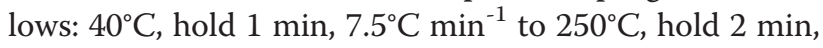
pulsed splitless injector held at $250^{\circ} \mathrm{C}$. Samples were also analyzed on an Agilent DB-WAX column (polyethylene glycol, $30 \mathrm{~m} \times 250 \mu \mathrm{m}$ ID, $0.25 \mu \mathrm{m}$ film) with the following temperature program: $40^{\circ} \mathrm{C}$, hold $3 \mathrm{~min}, 10^{\circ} \mathrm{C} \mathrm{min}^{-1}$ to $240^{\circ} \mathrm{C}$, hold $15 \mathrm{~min}$, pulsed splitless injector held at $240^{\circ} \mathrm{C}$. Compounds were identified by comparison of mass spectra and retention indices with authentic standards if available, and retention indices, and/or mass spectra from Adams [52] and NIST, and combined mass spectra and retention index library searches in MassFinder [53] if standards were not available.

When possible, stereochemistry of enzyme products were compared to authentic chiral standards on an Agilent Cyclodex B column (permethylated $\beta$-cyclodextrin in DB 1701 ((14\%-cyanopropyl-phenyl)-methylpolysiloxane), $30 \mathrm{~m} \times 250 \mu \mathrm{m}$ ID, $0.25 \mu \mathrm{m}$ film) with the following 
temperature program: $55^{\circ} \mathrm{C}$, hold $1 \mathrm{~min}, 1^{\circ} \mathrm{C} \min ^{-1}$ to $100^{\circ} \mathrm{C}, 10^{\circ} \mathrm{C} \mathrm{min}^{-1}$ to $240^{\circ} \mathrm{C}$, hold $10 \mathrm{~min}$, pulsed splitless injector held at $230^{\circ} \mathrm{C}$.

\section{Phylogenetic analysis}

Protein alignments were prepared using MUSCLE [54] and phylogenetic trees were constructed using the neighbour-joining method with 100 bootstrap repetitions, both within CLC Main Workbench 5.6.1 (CLC bio, Århus, Denmark).

\section{Molecular modelling}

We used Deep View/Swiss-PDBViewer (Mac version 3.9.1b) and SWISS-MODEL [55-57] to develop a 3D homology model of WS00725_G07c1 truncated at Q63 based on the structure of limonene synthase from Mentha spicata containing the substrate analogue 2-fluorogeranyl diphosphate (Protein Data Bank 2ONGB) [35].

\section{List of abbreviations}

TPS: terpene synthase; EST: expressed sequence tag; FLCDNA: full-length CDNA; GPP: geranyl diphosphate; FPP: farnesyl diphosphate; GGPP: geranylgeranyl diphosphate; GC: gas chromatography; MS: mass spectrometry; ORF: open reading frame; MeJA: methyl jasmonate; gene and enzyme names abbreviations are shown in Table 3.

\section{Acknowledgements and Funding}

We thank Ms. Lina Madilao for GCMS support, and Ms. Karen Reid for excellent laboratory management support and for generating much of the sequence information used for the analysis shown in Table 1. This research was supported by a discovery grant to JB from the Natural Sciences and Engineering Research Council (NSERC), and with funds from Genome British Columbia and Genome Canada to JB in support of the Treenomix Conifer Forest Health Project (http://www.treenomix.ca). JB was supported in part by the UBC Distinguished University Scholars program and an NSERC Steacie Memorial Fellowship.

\section{Author details}

Michael Smith Laboratories, University of British Columbia, 301-2185 East Mall, Vancouver BC, V6T 1Z4, Canada. ${ }^{2}$ Roche Diagnostics Ltd., Forrenstrasse, $\mathrm{CH}-6343$ Rotkreuz, Switzerland. ${ }^{3}$ Department of Biology, University of North Dakota, Grand Forks, ND, 58202-9019, USA. ${ }^{4}$ Department of Plant Biology and Biotechnology, University of Copenhagen, Thorvaldsensvej 40, opg. 10, 1.-1871 Frederiksberg, Denmark.

\section{Authors' contributions}

CIK, SGR, and JB conceived the research. SGR and SJ selected and sequenced the clones for functional characterization and completed RACE. CIK, SW, BH, and HKD cloned, expressed and/or functionally characterized the clones. CIK and JB wrote the manuscript. All authors read and approved the final manuscript.

Received: 21 December 2010 Accepted: 7 March 2011 Published: 7 March 2011

\section{References}

1. Franceschi VR, Krokene P, Christiansen E, Krekling T: Anatomical and chemical defenses of conifer bark against bark beetles and other pests. New Phytol 2005, 167:353-376.

2. Keeling $\mathrm{Cl}$, Bohlmann J: Genes, enzymes and chemicals of terpenoid diversity in the constitutive and induced defence of conifers against insects and pathogens. New Phytol 2006, 170:657-675.

3. Keeling $\mathrm{Cl}$, Bohlmann J: Diterpene resin acids in conifers. Phytochemistry 2006, 67:2415-2423.
4. Becerra JX, Noge K, Venable DL: Macroevolutionary chemical escalation in an ancient plant-herbivore arms race. Proc Natl Acad Sci USA 2009, 106:18062-18066.

5. Ro D-K, Arimura G, Lau SY, Piers E, Bohlmann J: Loblolly pine abietadienol/ abietadienal oxidase PtAO (CYP720B1) is a multifunctional, multisubstrate cytochrome P450 monooxygenase. Proc Natl Acad Sci USA 2005, 102:8060-8065.

6. Aubourg S, Lecharny A, Bohlmann J: Genomic analysis of the terpenoid synthase (AtTPS) gene family of Arabidopsis thaliana. Mol Genet Genomics 2002, 267:730-745

7. Goff SA, Ricke D, Lan T-H, Presting G, Wang R, Dunn M, Glazebrook J, Sessions A, Oeller $P$, Varma $H$, et al: A draft sequence of the rice genome (Oryza sativa L. ssp. japonica). Science 2002, 296:92-100.

8. Tuskan GA, Difazio S, Jansson S, Bohlmann J, Grigoriev I, Hellsten U, Putnam N, Ralph S, Rombauts S, Salamov A, et al: The genome of black cottonwood, Populus trichocarpa (Torr. \& Gray). Science 2006, 313:1596-1604.

9. Jaillon O, Aury JM, Noel B, Policriti A, Clepet C, Casagrande A, Choisne N, Aubourg S, Vitulo N, Jubin C, et al: The grapevine genome sequence suggests ancestral hexaploidization in major angiosperm phyla. Nature 2007, 449:463-467.

10. Martin DM, Aubourg S, Schouwey MB, Daviet L, Schalk M, Toub O, Lund ST, Bohlmann J: Functional annotation, genome organization and phylogeny of the grapevine (Vitis vinifera) terpene synthase gene family based on genome assembly, FLcDNA cloning, and enzyme assays. BMC Plant Biol 2010, 10:226.

11. Hamberger B, Hall D, Yuen M, Oddy C, Hamberger B, Keeling Cl, Ritland C, Ritland K, Bohlmann J: Targeted isolation, sequence assembly and characterization of two white spruce (Picea glauca) BAC clones for terpenoid synthase and cytochrome P450 genes involved in conifer defence reveal insights into a conifer genome. BMC Plant Biol 2009, 9:106.

12. Keeling Cl, Dullat HK, Yuen M, Ralph SG, Jancsik S, Bohlmann J: Identification and functional characterization of monofunctional entcopalyl diphosphate and ent-kaurene synthases in white spruce (Picea glauca) reveal different patterns for diterpene synthase evolution for primary and secondary metabolism in gymnosperms. Plant Physiol 2010 152:1197-1208

13. Bohlmann J, Phillips M, Ramachandiran V, Katoh S, Croteau R: cDNA cloning, characterization, and functional expression of four new monoterpene synthase members of the Tpsd gene family from grand fir (Abies grandis). Arch Biochem Biophys 1999, 368:232-243.

14. Martin DM, Fäldt J, Bohlmann J: Functional characterization of nine Norway spruce TPS genes and evolution of gymnosperm terpene synthases of the TPS-d subfamily. Plant Physiol 2004, 135:1908-1927.

15. Pavy N, Paule C, Parsons L, Crow JA, Morency MJ, Cooke J, Johnson JE, Noumen E, Guillet-Claude C, Butterfield Y, et al: Generation, annotation, analysis and database integration of 16,500 white spruce EST clusters. BMC Genomics 2005, 6:144.

16. Ralph SG, Chun HJ, Kolosova N, Cooper D, Oddy C, Ritland CE, Kirkpatrick R, Moore R, Barber S, Holt RA, et al: A conifer genomics resource of 200,000 spruce (Picea spp.) ESTs and 6,464 high-quality, sequence-finished fulllength cDNAs for Sitka spruce (Picea sitchensis). BMC Genomics 2008, 9:484.

17. Cairney J, Zheng L, Cowels A, Hsiao J, Zismann V, Liu J, Ouyang S, ThibaudNissen F, Hamilton J, Childs $K$, et al: Expressed sequence tags from loblolly pine embryos reveal similarities with angiosperm embryogenesis. Plant Mol Biol 2006, 62:485-501.

18. Steele CL, Crock J, Bohlmann J, Croteau R: Sesquiterpene synthases from grand fir (Abies grandis) - Comparison of constitutive and woundinduced activities, and cdna isolation, characterization and bacterial expression of $\delta$-selinene synthase and $\gamma$-humulene synthase. J Biol Chem 1998, 273:2078-2089.

19. Greenhagen BT, O'Maille PE, Noel JP, Chappell J: Identifying and manipulating structural determinates linking catalytic specificities in terpene synthases. Proc Natl Acad Sci USA 2006, 103:9826-9831.

20. Hyatt DC, Croteau R: Mutational analysis of a monoterpene synthase reaction: Altered catalysis through directed mutagenesis of (-)-pinene synthase from Abies grandis. Arch Biochem Biophys 2005, 439:222-233.

21. O'Maille PE, Malone A, Dellas N, Andes Hess B Jr, Smentek L, Sheehan I, Greenhagen BT, Chappell J, Manning G, Noel JP: Quantitative exploration of the catalytic landscape separating divergent plant sesquiterpene synthases. Nat Chem Biol 2008, 4:617-623. 
22. Little DB, Croteau RB: Alteration of product formation by directed mutagenesis and truncation of the multiple-product sesquiterpene synthases $\delta$-selinene synthase and $\gamma$-humulene synthase. Arch Biochem Biophys 2002, 402:120-135.

23. Yoshikuni Y, Ferrin TE, Keasling JD: Designed divergent evolution of enzyme function. Nature 2006, 440:1078-1082.

24. Keeling Cl, Weisshaar S, Lin RPC, Bohlmann J: Functional plasticity of paralogous diterpene synthases involved in conifer defence. Proc Natl Acad Sci USA 2008, 105:1085-1090.

25. Tholl D, Chen F, Petri J, Gershenzon J, Pichersky E: Two sesquiterpene synthases are responsible for the complex mixture of sesquiterpenes emitted from Arabidopsis flowers. Plant J 2005, 42:757-771.

26. Bohlmann J, Gershenzon J: Old substrates for new enzymes of terpenoid biosynthesis. Proc Natl Acad Sci USA 2009, 106:10402-10403.

27. Sallaud C, Rontein D, Onillon S, Jabes F, Duffe P, Giacalone C, Thoraval S, Escoffier C, Herbette G, Leonhardt N, et al: A novel pathway for sesquiterpene biosynthesis from $Z, Z$-farnesyl pyrophosphate in the wild tomato Solanum habrochaites. Plant Cell 2009, 21:301-317.

28. Schilmiller AL, Schauvinhold I, Larson M, Xu R, Charbonneau AL, Schmidt A, Wilkerson C, Last RL, Pichersky E: Monoterpenes in the glandular trichomes of tomato are synthesized from a neryl diphosphate precursor rather than geranyl diphosphate. Proc Natl Acad Sci USA 2009, 106:10865-10870.

29. Miller B, Madilao LL, Ralph S, Bohlmann J: Insect-induced conifer defense. White pine weevil and methyl jasmonate induce traumatic resinosis, de novo formed volatile emissions, and accumulation of terpenoid synthase and putative octadecanoid pathway transcripts in Sitka spruce. Plant Physiol 2005, 137:369-382.

30. Robert JA, Madilao LL, White R, Yanchuk A, King J, Bohlmann J: Terpenoid metabolite profiling in Sitka spruce identifies association of dehydroabietic acid, (+)-3-carene, and terpinolene with resistance against white pine weevil. Botany 2010, 88:810-820.

31. Byun-McKay A, Godard K-A, Toudefallah M, Martin D, Alfaro R, King J, Bohlmann J, Plant AL: Wound-induced terpene synthase gene expression in Sitka spruce that exhibit resistance or susceptibility to attack by the white pine weevil. Plant Physiol 2006, 140:1009-1021.

32. Byun McKay SA, Hunter WL, Godard KA, Wang SX, Martin DM, Bohlmann J, Plant $A L$ : Insect attack and wounding induce traumatic resin duct development and gene expression of (-)-pinene synthase in Sitka spruce. Plant Physiol 2003, 133:368-378.

33. Phillips MA, Wildung MR, Williams DC, Hyatt DC, Croteau R: CDNA isolation, functional expression, and characterization of $(+)$-a-pinene synthase and (-)-a-pinene synthase from loblolly pine (Pinus taeda): stereocontrol in pinene biosynthesis. Arch Biochem Biophys 2003, 411:267-276.

34. Bohlmann J, Steele CL, Croteau R: Monoterpene synthases from grand fir (Abies grandis). cDNA isolation, characterization, and functional expression of myrcene synthase, (-)-(4S)-limonene synthase, and (-)-(1S,5S)-pinene synthase. J Biol Chem 1997, 272:21784-21792.

35. Hyatt DC, Youn B, Zhao Y, Santhamma B, Coates RM, Croteau RB, Kang C: Structure of limonene synthase, a simple model for terpenoid cyclase catalysis. Proc Natl Acad Sci USA 2007, 104:5360-5365.

36. Martin D, Tholl D, Gershenzon J, Bohlmann J: Methyl jasmonate induces traumatic resin ducts, terpenoid resin biosynthesis, and terpenoid accumulation in developing xylem of Norway spruce stems. Plant Physiol 2002, 129:1003-1018.

37. Martin DM, Gershenzon J, Bohlmann J: Induction of volatile terpene biosynthesis and diurnal emission by methyl jasmonate in foliage of Norway spruce. Plant Physiol 2003, 132:1586-1599.

38. Zulak KG, Lippert DN, Kuzyk MA, Domanski D, Chou T, Borchers CH, Bohlmann J: Targeted proteomics using selected reaction monitoring reveals the induction of specific terpene synthases in a multi-level study of methyl jasmonate-treated Norway spruce (Picea abies). Plant J 2009, 60:1015-1030.

39. Abbott $E$, Hall D, Hamberger B, Bohlmann J: Laser microdissection of conifer stem tissues: isolation and analysis of high quality RNA, terpene synthase enzyme activity and terpenoid metabolites from resin ducts and cambial zone tissue of white spruce (Picea glauca). BMC Plant Biol 2010, 10:106.

40. Zulak KG, Dullat HK, Keeling Cl, Lippert D, Bohlmann J: Immunofluorescence localization of levopimaradiene/abietadiene synthase in methyl jasmonate treated stems of Sitka spruce (Picea sitchensis) shows activation of diterpenoid biosynthesis in cortical and developing traumatic resin ducts. Phytochemistry 2010, 71:1695-1699.

41. Hall D, Robert JA, Keeling Cl, Domanski D, Lara Quesada A, Jancsik S, Kuzyk M, Hamberger B, Borchers CH, Bohlmann J: An integrated genomic, proteomic and biochemical analysis of (+)-3-carene biosynthesis in Sitka spruce (Picea sitchensis) genotypes that are resistant or susceptible to white pine weevil. Plant J 2011, 65:936-948.

42. Fäldt J, Martin D, Miller B, Rawat S, Bohlmann J: Traumatic resin defense in Norway spruce (Picea abies): methyl jasmonate-induced terpene synthase gene expression, and cDNA cloning and functional characterization of (+)-3-carene synthase. Plant Mol Biol 2003, 51:119-133.

43. Andersson MN, Larsson MC, Blazenec M, Jakus R, Zhang QH, Schlyter F: Peripheral modulation of pheromone response by inhibitory host compound in a beetle. J Expt Biol 2010, 213:3332-3339.

44. Green S, Friel EN, Matich A, Beuning LL, Cooney JM, Rowan DD, MacRae E: Unusual features of a recombinant apple a-farnesene synthase. Phytochemistry 2007, 68:176-188.

45. Köpke D, Schroder R, Fischer HM, Gershenzon J, Hilker M, Schmidt A: Does egg deposition by herbivorous pine sawflies affect transcription of sesquiterpene synthases in pine? Planta 2008, 228:427-438.

46. Otomo K, Kanno Y, Motegi A, Kenmoku H, Yamane H, Mitsuhashi W, Oikawa $H$, Toshima $H$, Itoh $H$, Matsuoka $M$, et al: Diterpene cyclases responsible for the biosynthesis of phytoalexins, momilactones $A, B$, and oryzalexins A-F in rice. Biosci Biotech Biochem 2004, 68:2001-2006.

47. Bohlmann J, Crock J, Jetter R, Croteau R: Terpenoid-based defenses in conifers: cDNA cloning, characterization, and functional expression of wound-inducible $(E)$-a-bisabolene synthase from grand fir (Abies grandis). Proc Natl Acad Sci USA 1998, 95:6756-6761.

48. Hayashi K, Kawaide H, Notomi M, Sakigi Y, Matsuo A, Nozaki H: Identification and functional analysis of bifunctional ent-kaurene synthase from the moss Physcomitrella patens. FEBS Letters 2006, 580:6175-6181.

49. Huang $X$, Madan A: CAP3: A DNA sequence assembly program. Genome Res 1999, 9:868-877.

50. Zeng G: Sticky-end PCR: new method for subcloning. BioTechniques 1998, 25:206-208.

51. O'Maille PE, Chappell J, Noel JP: A single-vial analytical and quantitative gas chromatography-mass spectrometry assay for terpene synthases. Anal Biochem 2004, 335:210-217.

52. Adams RP: Identification of Essential Oil Components by Gas Chromatography/Mass Spectrometry. Carol Stream, IL, USA: Allured Publishing Co; 42007.

53. Hochmuth DH: MassFinder 3. Hamburg, Germany; 2007.

54. Edgar RC: MUSCLE: multiple sequence alignment with high accuracy and high throughput. Nucleic Acids Res 2004, 32:1792-1797.

55. Arnold K, Bordoli L, Kopp J, Schwede T: The SWISS-MODEL workspace: a web-based environment for protein structure homology modelling. Bioinformatics 2006, 22:195-201.

56. Guex N, Peitsch MC: SWISS-MODEL and the Swiss-PdbViewer: An environment for comparative protein modeling. Electrophoresis 1997, 18:2714-2723.

57. Schwede T, Kopp J, Guex N, Peitsch MC: SWISS-MODEL: An automated protein homology-modeling server. Nucleic Acids Res 2003, 31:3381-3385.

doi:10.1186/1471-2229-11-43

Cite this article as: Keeling et al:: Transcriptome mining, functional characterization, and phylogeny of a large terpene synthase gene family in spruce (Picea spp.). BMC Plant Biology 2011 11:43. 